\title{
Review Article \\ Role of G Protein-Coupled Receptors in Control of Dendritic Cell Migration
}

\author{
Yuan Liu and Guixiu Shi \\ Department of Rheumatology and Clinical Immunology, The First Affiliated Hospital, Xiamen University, \\ No. 55, Zhenhai Road, Xiamen 361003, China \\ Correspondence should be addressed to Guixiu Shi; guixiu.shi@gmail.com
}

Received 4 December 2013; Revised 30 January 2014; Accepted 3 February 2014; Published 10 March 2014

Academic Editor: Mina Hur

Copyright (C) 2014 Y. Liu and G. Shi. This is an open access article distributed under the Creative Commons Attribution License, which permits unrestricted use, distribution, and reproduction in any medium, provided the original work is properly cited.

Dendritic cells (DCs) are highly efficient antigen-presenting cells. The migratory properties of DCs give them the capacity to be a sentinel of the body and the vital role in the induction and regulation of adaptive immune responses. Therefore, it is important to understand the mechanisms in control of migration of DCs to lymphoid and nonlymphoid tissues. This may provide us novel insight into the clinical treatment of diseases such as autoimmune disease, infectious disease, and tumor. The chemotactic $\mathrm{G}$ proteincoupled receptors (GPCR) play a vital role in control of DCs migration. Here, we reviewed the recent advances regarding the role of GPCR in control of migration of subsets of DCs, with a focus on the chemokine receptors. Understanding subsets of DCs migration could provide a rational basis for the design of novel therapies in various clinical conditions.

\section{Introduction}

Migration of immune cells is a fundamental biological process involved in normal physiology. This process increases the chance that lymphocytes will encounter the antigen and is also critical to the development of an inflammatory response. Abnormal immune cells migration is always associated with the development and progression of autoimmune diseases [1-3]. Many studies have provided strong support for this idea, and clinical studies have indicated that pharmacological inhibitors on immune cells migration can be highly effective in certain disease conditions $[4,5]$.

Dendritic cells (DCs) are highly efficient antigen-presenting cells (APC). Several subsets of DCs exist in mice and humans with distinct immunological activities, tissue distribution, and migratory properties. Following uptake of Antigen and in response to inflammatory signals, DCs reside within peripheral tissue become mature and migrate to lymph nodes where they initiate the acquired immunity [6]. In addition to activating the immune response, DCs are also decisive in creating tolerance [7]. The migratory properties of DCs give them capacity to be a sentinel of the body in recognizing the alloantigens, xenoantigens, autoantigens, and neoantigens, and give them the vital role in the induction and regulation of adaptive immune responses. Therefore, it is important to understand the mechanisms in control of migration of DCs, which may provide us novel insight into the clinical treatment of diseases such as autoimmune disease, infectious disease, and tumor.

$\mathrm{G}$ protein-coupled receptors (GPCR), the 7 transmembrane receptors, encoded by more than 800 genes, are activated by a large variety of factors ranging from small amines to hormones and chemokines [8]. Chemokines are the most well-known factors in the induction of immune cell migration, and all chemokine receptors identified so far are membrane-bound GPCRs. Besides chemokines, several bioactive lipids or hormones such as Sphingosine 1-phosphate (S1P), Lysophosphatidic acid (LPA), and angiotensin II can also regulate the migration of DCs by binding to receptors coupled to G proteins [9-11]. GPCRs play a central role in control of DCs migration. In this review, we focused on the role of chemokine receptors in control of migration of DCs. 


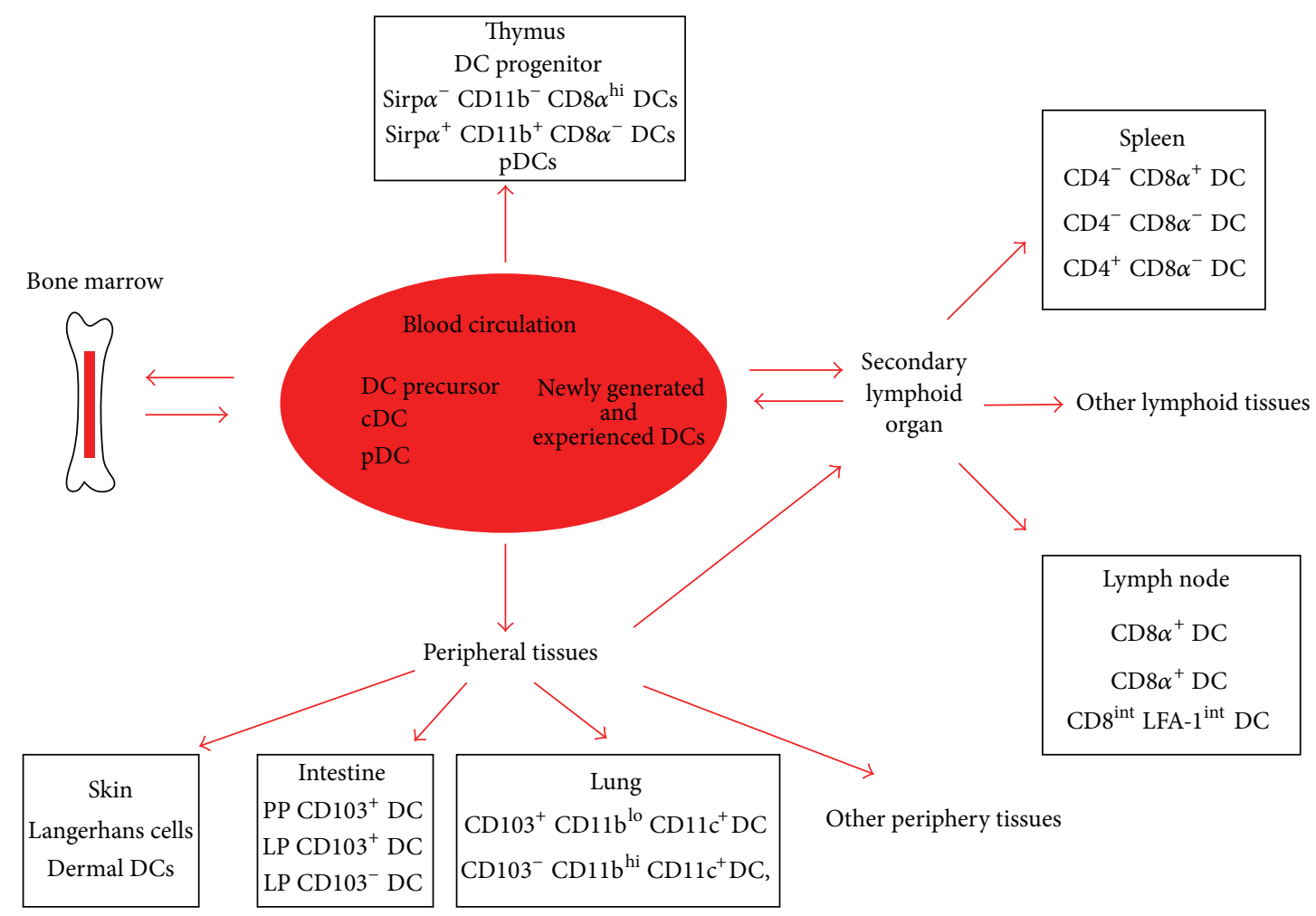

FIGURE 1: Schematic illustration of routes of migration of mouse DCs. DC precursors are released from the BM into the blood; DC progenitors can also be found in multiple locations including the thymus, blood, lymph, and most visceral organs. DC precursors seeded peripheral lymphoid tissues and nonlymphoid tissues and differentiated them into committed DCs. cDCs in peripheral tissues can access afferent lymph upon receiving a mobilization signal and travel to the draining LNs during both inflammation and steady-stated. pDCs travel to the LNs and spleen via hematogenous route. Some DCs might exit lymph nodes (LN) and start a still undefined pathway to recirculate. The circulating DCs in the blood contain both DC precursors and differentiated DC subsets, which are a mixture of newly generated cells from the BM and experienced DCs which have reentered the circulation from peripheral tissues.

\section{Subsets of Dendritic Cells and Routes of Dendritic Cells Trafficking}

Definition of subsets of DCs is still evolving with new technology. Dendritic cell was first discovered in peripheral lymphoid organs in the late 1970s [12]. Soon after that, DCs populate in nonlymphoid tissue such as Langerhans cell (LC) were identified. Classical mouse DCs in lymphoid tissue were further subdivided into two subsets by the presence or absence of CD8 expression $\left(\mathrm{CD}^{+}\right.$and $\left.\mathrm{CD}^{+1} \mathrm{~b}^{+} \mathrm{cDCs}\right)$, and DCs in nonlymphoid tissue were subdivided by the expression of integrin CD103 $\left(\mathrm{CD}_{103}{ }^{+} \mathrm{CD} 1 \mathrm{~b}^{-}\right.$and $\mathrm{CD}_{11 b^{+}}$ cDCs) $[13,14]$. However, human DCs did not express CD8, they can be split into $\mathrm{CD} 1 \mathrm{c}^{+}$and $\mathrm{CD} 141^{+}$subsets which share homology with mouse classical DCs expressing either CD11b (CD1c ${ }^{+}$DCs) or CD8/CD103 (CD141 ${ }^{+}$DCs) [15].

In recent years, a population of DCs which morphologically resemble plasma cells but, upon exposure to viral stimuli, produce enormous amounts of interferon (IFN)- $\alpha$, was identified and named as plasmacytoid dendritic cells (pDCs). The definition of classical DCs (cDCs) then came out which referred to DCs other than pDCs. DCs can also be classified into myeloid DCs and lymphoid DCs based on their origin. Phenotype characteristics and immune function of subsets of DCs were summarized by Merad et al. [16]. Subsets of DCs are different in migratory routes.

Most of the conclusions about the migration of DCs came from researches on mouse DCs. All DCs are thought to be ultimately derived from bone marrow (BM) [17]. Many DCs begin their journey with their release from the $\mathrm{BM}$ into the blood. Circulating DCs in the blood contain both DC precursors and differentiated DC subsets, which are a mixture of newly generated cells from the BM and experienced DCs. DCs in the blood subsequently traffic to lymphoid and nonlymphoid tissues. DCs in peripheral tissues such as skin, lung, and intestine migrate to draining lymph nodes to initiate acquired immunity during inflammation state, and this migration also happens in steady-state. A small fraction of these experienced DCs can reenter into the blood circulation and begin another cycle of journey. Unlike cDCs, pDCs are rarely found in peripheral tissues except for the intestine and enter the LN via the high endothelial venules (HEV) instead of afferent lymphatics. pDCs have been reported to migrate to sites of inflammation and to infiltrate tumors as well as solid organ transplants [18]. The routes of migration of mouse DCs are schematic illustrated in Figure 1. 


\section{Chemokine Receptors and DCs Migration}

Chemokines are small molecular weight chemoattractant peptides first identified and characterized as being induced at sites of inflammation and thought to orchestrate the influx of leucocytes to the inflamed tissue. To date, more than 40 chemokines have been identified and classified into four families, $\mathrm{C}, \mathrm{CC}, \mathrm{CXC}$, and $\mathrm{CX} 3 \mathrm{C}$, according to the motif displayed by the first two of four cysteine residues at the $\mathrm{N}$ terminus of the molecule [19]. The specific effect of chemokines is mediated by their $\mathrm{G}$ protein-coupled receptors. DCs migration is largely mediated by the interaction of chemokines with their $\mathrm{G}$ protein-coupled receptors. Selective expression of chemokine receptors on DCs tightly regulates the normal and inflammatory trafficking within lymphoid and nonlymphoid tissues [20].

There are 18 chemokine receptors that have been identified so far, receptors for fractalkine (CX3CR1) and lymphotactin (XCR1), 5 receptors that selectively bind certain CXC chemokines named as CXCR1 to CXCR5, 9 receptors which bind to CC chemokine named as CCR1 to CCR9, D6 which has been termed as CCR10 by some research group, and receptor which can bind to both CXC and CC chemokines known as the Duffy antigen receptor for chemokines (DARC) [21].

Studies on the in vitro derived DCs $\left(\mathrm{CD} 34^{+}\right.$stem cell or bone marrow-derived DCs) found that immature DCs can express CCR1, CCR2, CCR5, CCR6, CXCR1, CXCR2, and CXCR4, with these expression patterns differing somewhat among DC subsets. However, chemokine receptors expression profile from the in vitro study may not accurately mirror the changes that occur on DCs in vivo. It has been indicated that several chemokine receptors including CCR1, CCR2, CCR3, CCR5, CCR6, CCR7, CCR9, CCR10, CXCR3, CXCR4, CXCR5, and ChemR23 are involved in control of different subsets of DCs recruitment to periphery tissues and migration to secondary lymphoid tissues or migration within lymphoid tissues.

\subsection{Chemokine Receptors and Mouse DCs Migration}

3.1.1. CCR1. Expression of CCR1 can be detected on immature DCs. Its ligand CCL9, also known as MIP- $\gamma$, is constitutively secreted by the follicle-associated epithelium (FAE) within the dome regions of the Peyer's patches in mouse, and it may play a role in the recruitment of $\mathrm{CD}_{11 b^{+}} \mathrm{DCs}$ in the dome regions of the Peyer's patches in addition to the CCR6dependent manner [22]. Study also indicated the possible role of CCR1 as well as CCR5 in regulation of recruitment of immature DC precursors into resting airway tissues and during acute bacterial-induced inflammation by using MetRANTES, which retained high binding affinity to CCR1 and CCR5. However, the effect of CCR1 in control of DCs migration appeared to depend on the nature of the eliciting stimulus, because the recruitment of DCs was not affected by Met-RANTES in inflammation induced by Sendai virus infection and after aerosol challenge of sensitized animals with the soluble recall Ag OVA [23]. These data suggest that CCR1 might play a role in recruitment of immature DCs to periphery tissues during both steady-state and inflammatorystate. However, all of these conclusions came from some indirect data, the direct effect of CCR1 in the DCs migration still needs to be proved.

3.1.2. CCR2. CCR2 is expressed on immature DCs, and its expression can be also detected in mature DCs [54]. Its main ligand is CCL2 [55]. Several studies demonstrated the central role of CCR2 in the recruitment of DCs to the lung during inflammation by using CCR 2 knockout mice. Robays and his colleague showed that CCR2 was involved in the recruitment of DCs in the lung during allergic inflammation and may mediate the release of DC precursors into the bloodstream, and CCR2 was critical in inducing Th2 responses [24, 25]. However, controversy existed about the role of CCR2 in the Th1 or Th2 induction. In the situation of fungal pathogen and mycobacterium tuberculosis infection, CCR2 was shown to be involved in recruitment of myeloid DCs and $\mathrm{CD}_{11} \mathrm{dim}^{\mathrm{dim} / \text { intermediate }} \mathrm{DCs}$ to the lung, respectively, and it was supposed to mount Th1 immune responses [26, 27]. Besides the role of CCR2 in the immature DCs trafficking, it can also regulate the migration of some activated DCs to the draining LNs. Study using CCR2-null mice showed that migration of Langerhans cell from skin to draining lymph nodes was impaired with reduced Th1-inducing DCs $\left(\mathrm{CD} 8 \alpha^{+} \mathrm{DC}\right)$ in the spleen and impaired infection-induced relocalization of $\mathrm{CD}_{11 \mathrm{c}^{+}} \mathrm{DC}$ from the marginal zone (MZ) to the $\mathrm{T}$ cell areas in spleen [28].

3.1.3. CCR5. CCR5 is the major HIV-1 coreceptors for R5 strains. CCR5 is shown to be expressed by immature blood DCs in human, and in vitro maturation of blood DCs resulted in median 3-fold increases in CCR5 expression [56]. Its ligands CCL3, CCL4, and CCL5 are produced in the inflamed LNs of humans and/or mice $[57,58]$. In mice, the role of CCR5 in the migration of pDCs to LNs has been demonstrated by several studies. By using CCR5 deficient pDCs (derived from BM of CCR5 - /- mice), Diacovo proved that migration of pDCs from blood to inflamed peripheral lymph nodes relied in part on CCR5 rather than CXCR3 [29].

3.1.4. CCR6. CCR6 is expressed by immature DCs, different in subsets of DCs (absent from CD8 $\alpha^{+}$lymphoid DC), and the expression level of CCR6 decreases progressively as DCs mature [59]. Its ligand CCL20 is expressed by inflamed skin, mucosal epithelium, and mucosal-associated lymphoid tissue epithelium, and it plays an important role in recruitment of immature DCs to inflamed skin or mucosa [20]. Study on the CCR6 deficient mice showed that myeloid CD11c ${ }^{+}$ $\mathrm{CD}_{11 b^{+}}$dendritic cells were absent from the subepithelial dome of Peyer's patches, which indicated the role of CCR6 in recruitment of myeloid DCs to the Peyer's patches [30, 31]. Similarly, studies also demonstrated the role of CCR6 in recruitment of myeloid DCs to the inflamed epithelial tissues such as skin [32]. Study also indicated that in some situation such as consecutive to an initial CCR7-mediated recruitment from blood into lymphoid tissues draining inflamed epithelia, pDCs might be conditioned to acquire CCR6 and CCR10 
expression and migrate into inflamed epithelia of mucosae or skin. This study suggests an unexpected pDCs migratory model, after CCR7-mediated extravasation of blood pDCs into lymphoid tissues draining inflamed epithelia, they may be instructed to up-regulate CCR6 and/or CCR10 allowing their homing into inflamed epithelia (in mucosae or skin) [33].

3.1.5. CCR7. CCR7 has been identified as a key regulator of lymphocytes trafficking to secondary lymphoid organs [60]. It is expressed by mature DCs [61]. CCL19 and CCL21 (also known as secondary lymphoid-tissue chemokine) are the two ligands of CCR7 which are found to express in the afferent lymphatic vessel and LN paracortex and subcapsular sinus (SCS) in mice [62]. The role of CCR7 in DCs migration has been well studied in mice DCs. Several studies demonstrated the role of CCR7 in control of tissueresident myeloid dendritic cells from periphery tissues such as skin and mucosa migration to draining LNs via the afferent lymphatics under inflammatory and steady-state conditions $[34,63]$. The role of CCR7 in migration of pDCs remains controversial. Some studies showed that murine pDCs were CCR7 negative or low, and functionally were considered unresponsive to CCR7 ligands $[64,65]$. However, studies using CCR7-deficient mice demonstrated the role of CCR7 in regulation of $\mathrm{pDCs}$ migration to secondary lymphoid organs. Sebastian found that ex vivo derived nonstimulated and naive pDC express CCR7, CCR7-deficient pDC showed impaired homing to resting as well as inflamed LN, and identified that CCR7 was an important LN homing receptor for $\mathrm{pDC}$ under both steady-state and inflammatory conditions [35]. Umemoto showed that CCR7 as well as CXCR4 were both critical chemokine receptors required for $\mathrm{pDCs}$ to migrate into white pulp in the spleen under steady-state conditions [36].

3.1.6. CCR9. CCR9 has first been identified on $\mathrm{T}$ cells as a chemokine receptor that directs these cells to migrate to the intestine. The CCR9 receptor is not unique to $\mathrm{T}$ cells and has also been reported on both myeloid and pDCs, and the expression level of CCR9 was inversely related to the maturation state of DCs [66]. CCL25, also known as thymusexpressed chemokine (TECK), is the ligand of CCR9, which is found in the thymic cortex and in the small intestinal mucosa $[67,68]$. It was reported that CCR9 controlled the migration of $\mathrm{pDC}$ to the small intestine under both steady-state and inflammatory conditions [37]. The $\mathrm{CCR}^{+}$pDCs in tissue was thought to be immunosuppressive population $[69,70]$. However, the role of CCR9 in myeloid DCs migration still needed to be investigated.

3.1.7. CXCR3. Study using the human CXCR3-specific monoclonal antibodies showed that CXCR3 was expressed in certain dendritic cells subsets, specifically myeloid-derived $\mathrm{CD}_{11 \mathrm{c}^{+}}$cells both in normal lymphoid organs and inflammatory conditions [71]. Study also showed that CXCR3 was functionally expressed in $\mathrm{pDCs}$ and induced migration of
pDCs. By using CXCR3 (-/-) mice, Yoneyama et al. demonstrated that CXCR3 played an important role in recruitment of pDC precursors to inflamed lymph nodes through high endothelial venules (HEV) in propionibacterium acnesprimed or HSV-infected mice [38]. And similarly, AsselinPaturel showed that murine CMV infection and systemic injection of TLR7 and TLR9 ligands can induce migration and clustering of splenic pDCs in the spleen marginal zone, which was dependent on CXCR3 [39]. However, in the study of Diacovo, it was showed that CCR5 instead of CXCR3 was required for $\mathrm{pDC}$ migration in response to heat-killed mycobacterium tuberculosis. This difference might be due to the different inflammatory conditions [29].

3.1.8. CXCR4. CXCR4 is the major HIV-1 coreceptors for $\mathrm{X} 4 \mathrm{HIV}-1$ strains. The expression of CXCR4 on immature DCs is low and is up-regulated during maturation [56]. Its ligand CXCL12 is one of the three most important chemokines (CCL19, CCL21, and CXCL12) which directs DCs migrate from sites of infection to secondary lymphoid organs. Kabashima found that CXCR4 was highly expressed on migrated cutaneous DCs and its ligand, CXCL12, was detected in the LYVE-1(+) lymphatic vessels in the skin. By using CXCR4 antagonist 4-F-Benzoyl-TN14003, they demonstrated that CXCR4 was required for migration of cutaneous dendritic cells to LNs [40]. Umemoto showed that CXCR4 as well as CCR7, cooperatively regulated pDCs migration to the splenic white pulp under steady-state conditions [36].

3.1.9. CXCR5. It was thought that expression of CXCR5 was restricted to mature, recirculating $B$ cells as well as small subpopulations of $\mathrm{CD}^{+}$and $\mathrm{CD}^{+} \mathrm{T}$ lymphocytes [72]. Study also indicated that CXCR5 can be expressed by activated DCs and may be involved in their migration to draining LNs. The CXCR5 ligand CXCL13, also known as B lymphocyte chemoattractant or (BLC), is highly expressed in $B$ cell zones of secondary lymphoid organs. Saeki showed that activated dermal type DCs expressed CXCR5 and these DCs utilize CXCR5 and BLC as a possible mechanism to migrate to B cell zones as well as T cell zones (TCZ) in draining LN in vivo. However, in vitro murine bone marrow derived DCs displayed less CXCR5 expression than the activated skin DCs, and they do not migrate to BLC $[41,73]$.

3.1.10. ChemR23. ChemR23 is a previously orphan protein $G$ coupled receptor highly expressed in immature pDCs and at lower levels in myeloid DCs. Chemerin is the natural ligand of the ChemR23 and a chemoattractant factor for human immature dendritic cells (DCs), macrophages, and NK cells [74]. It played a central role in human pDCs migration. It was reported that ChemR23 was not present on mouse DCs [75]. However, Souphalone demonstrated that ChemR23 was functionally expressed by mouse DCs and mediated an antiinflammatory activity in a lung disease model [74]. These controversies on the expression of ChemR23 on mouse DCs are presumably the result of the different sensitivity of the Abs used in these studies. 
TABLE 1: Chemokine receptors and chemokines involved in migration of mouse DCs subsets.

\begin{tabular}{|c|c|c|c|c|}
\hline Receptor & Ligands & Cellular distribution & Role in migration & Reference \\
\hline \multirow{2}{*}{ CCR1 } & \multirow{2}{*}{ MIP-1 $\gamma /$ CCL9 } & \multirow{2}{*}{ Immature DCs } & $\begin{array}{l}\text { Recruitment of } \mathrm{CD} 1 \mathrm{~b}^{+} \text {DCs to the dome regions } \\
\text { of Peyer's patch }\end{array}$ & {$[22]$} \\
\hline & & & $\begin{array}{l}\text { Recruitment of DC precursors into airway } \\
\text { epithelium during bacterial inflammation and } \\
\text { steady-state }\end{array}$ & {$[23]$} \\
\hline \multirow{3}{*}{ CCR2 } & \multirow{3}{*}{ CCL2/MCP-1 } & \multirow[t]{2}{*}{ Immature DCs } & $\begin{array}{l}\text { Recruitment of DCs in the lung during allergic } \\
\text { inflammation, and supposed to be critical in } \\
\text { inducing } \mathrm{T}(\mathrm{H}) 2 \text { responses }\end{array}$ & {$[24,25]$} \\
\hline & & & $\begin{array}{l}\text { Recruitment of CD11c }{ }^{\text {dim/intermediate }} \text { DCs in the lung } \\
\text { during mycobacterium tuberculosis infection and } \\
\text { cDCs during Cryptococcus neoformans infection, } \\
\text { may be important in inducing } \mathrm{T}(\mathrm{H}) 1 \text { responses }\end{array}$ & {$[26,27]$} \\
\hline & & Mature DCs & $\begin{array}{l}\text { Activated LC migrate from skin to draining LNs } \\
\text { and regulate infection-induced relocalization of } \\
\text { CD11c }{ }^{+} \text {DC in spleen }\end{array}$ & {$[28]$} \\
\hline CCR5 & $\begin{array}{l}\text { MIP- } 1 \alpha / C C L 3 \\
\text { MIP-1 } \beta / C C L 4 \\
\text { Rantes/CCL5 } \\
\end{array}$ & $\begin{array}{l}\text { Immature DCs } \\
\text { mature DCs }\end{array}$ & $\begin{array}{l}\text { Recruitment of pDC to inflamed peripheral } \\
\text { lymph nodes }\end{array}$ & {$[29]$} \\
\hline \multirow{3}{*}{ CCR6 } & \multirow{3}{*}{ CCL20/MIP-3 $\alpha$} & \multirow{3}{*}{$\begin{array}{l}\text { Immature myeloid DC, } \\
\text { subsets of pDCs }\end{array}$} & $\begin{array}{l}\text { Recruitment of myeloid } \mathrm{CD} 1 \mathrm{c}^{+} \mathrm{CD} 1 \mathrm{~b}^{+} \text {dendritic } \\
\text { cells to the dome regions of Peyer's patches }\end{array}$ & {$[30,31]$} \\
\hline & & & $\begin{array}{l}\text { Recruitment of myeloid DCs to the inflamed } \\
\text { epithelial tissues such as skin }\end{array}$ & {$[32]$} \\
\hline & & & mediate pDC recruitment to inflamed epithelia & {$[33]$} \\
\hline \multirow[t]{3}{*}{ CCR7 } & \multirow[t]{3}{*}{$\begin{array}{l}\text { CCL19/MIP-3 } \beta \\
\text { CCL21/SLC }\end{array}$} & \multirow[t]{3}{*}{ Mature DCs } & $\begin{array}{l}\text { essential for directing the antigen-loaded mature } \\
\text { cDCs to the T cell-rich areas of the draining } \\
\text { lymph node during inflammatory and } \\
\text { steady-state conditions }\end{array}$ & {$[34]$} \\
\hline & & & $\begin{array}{l}\text { Migration of pDCs to LNs via HEV under both } \\
\text { steady-state and inflammatory conditions }\end{array}$ & {$[35]$} \\
\hline & & & $\begin{array}{l}\text { Migration of pDC to the splenic white pulp under } \\
\text { steady-state conditions }\end{array}$ & {$[36]$} \\
\hline CCR9 & CCL25 & Myeloid and pDC & $\begin{array}{l}\text { Controls the migration of pDC to the small } \\
\text { intestine under both steady-state and } \\
\text { inflammatory conditions }\end{array}$ & {$[37]$} \\
\hline CCR10 & $\begin{array}{l}\text { CCL27 } \\
\text { CCL28 }\end{array}$ & $\begin{array}{l}\text { Subset of tonsil pDCs, } \\
\text { IL-3-cultured blood pDCs }\end{array}$ & Mediate pDC homing into inflamed epithelia & {$[33]$} \\
\hline \multirow[t]{2}{*}{ CXCR3 } & \multirow{2}{*}{$\begin{array}{l}\text { CXCL9 } \\
\text { CXCL10/IP-10 } \\
\text { CXCL11 }\end{array}$} & \multirow{2}{*}{$\begin{array}{l}\text { pDC precursors } \\
\text { pDC } \\
\text { CD11c }{ }^{+} \text {myeloid DCs } \\
\text { monocyte-derived iDC }\end{array}$} & \multirow{2}{*}{$\begin{array}{l}\text { Migration of pDC to inflamed LNs via HEV } \\
\text { migration and clustering of splenic plasmacytoid } \\
\text { DCs in the spleen marginal zone }\end{array}$} & {$[38]$} \\
\hline & & & & [39] \\
\hline \multirow{2}{*}{ CXCR4 } & \multirow{2}{*}{ CXCL12/SDF-1 $\alpha$} & \multirow{2}{*}{$\begin{array}{l}\text { Immature DCs } \\
\text { mature DCs } \\
\text { pDC }\end{array}$} & Migration of skin dendritic cells to LNs & {$[40]$} \\
\hline & & & $\begin{array}{l}\text { Migration of pDC to the splenic white pulp under } \\
\text { steady-state conditions }\end{array}$ & {$[36]$} \\
\hline CXCR5 & CXCL13/BLC/BCA-1 & Activated skin DC & Activated dermal DC migrate to draining LNs & {$[41]$} \\
\hline
\end{tabular}

3.2. Chemokine Receptors in Human DCs Migration and Their Role in Diseases. Studies on the role of CCRs in human DCs migration are relatively few compared to studies in mouse. Most conclusions came from indirect evidence by using specific antibody or by analyzing their expression to speculate their role in human DCs migration.

Sato et al. indicated the role of CCR1 and CCR3 in human peripheral blood monocyte-derived dendritic cells migration by using monoclonal antibody (MoAb) to CCR1 and CCR3
[42]. Human cytomegalovirus may use a mechanism by down-regulating CCR1 and CCR5 expression on human DCs to paralyze the early immune response of the host [76], and filarial infection can also down-regulate the CCR1 expression on monocyte-derived DCs which may alter DCs migration [77].

By analyzing the expression of CCR2 and CCR6 on subsets of DCs as well as the ligands of CCR2 and CCR6 expression in different sites in the body, Vanbervliet 
TABLE 2: Chemokine receptors and chemokines involved in migration of human DCs subsets.

\begin{tabular}{|c|c|c|c|c|}
\hline Receptor & Ligands & Cellular distribution & Role in migration & Reference \\
\hline CCR1 & MIP-1 $\gamma /$ CCL9 & Immature DCs & $\begin{array}{l}\text { May be involved in human peripheral blood } \\
\text { monocyte-derived dendritic cells migration }\end{array}$ & {$[42]$} \\
\hline CCR2 & CCL2/MCP-1 & $\begin{array}{l}\text { Immature } \\
\text { mature DCs }\end{array}$ & $\begin{array}{l}\text { Recruitment of circulating blood DCs and } \\
\text { monocytes to inflamed tissue }\end{array}$ & {$[43]$} \\
\hline CCR3 & $\begin{array}{l}\text { Eotaxin } \\
\text { eotaxin-2 }\end{array}$ & $\begin{array}{l}\text { Immature DCs } \\
\text { mature DCs }\end{array}$ & May be involved in dendritic cells migration & {$[42,44]$} \\
\hline \multirow{3}{*}{ CCR5 } & \multirow{3}{*}{$\begin{array}{l}\text { MIP- } 1 \alpha / C C L 3 \\
\text { MIP-1 } \beta / C C L 4 \\
\text { Rantes/CCL5 }\end{array}$} & \multirow{3}{*}{$\begin{array}{l}\text { Immature DCs } \\
\text { mature DCs }\end{array}$} & $\begin{array}{l}\text { Attract DCs to migrate cross the human intestinal } \\
\text { epithelium and sample luminal virions }\end{array}$ & {$[45]$} \\
\hline & & & $\begin{array}{l}\text { May contribute to the recruitment of blood } \\
\text { myeloid DC to cerebrospinal fluid in multiple } \\
\text { sclerosis patients and acute optic neuritis. }\end{array}$ & {$[46]$} \\
\hline & & & $\begin{array}{l}\text { May be involved in the altered homing of blood } \\
\text { DCs during the alloimmune response }\end{array}$ & {$[47]$} \\
\hline \multirow[t]{2}{*}{ CCR6 } & \multirow[t]{2}{*}{ CCL20/MIP-3 $\alpha$} & \multirow[t]{2}{*}{$\mathrm{pDCs}$} & $\begin{array}{l}\text { May be involved in leukemic pDCs and blood } \\
\text { pDCs from melanoma patients recruitment to } \\
\text { lesions of skin }\end{array}$ & {$[48,49]$} \\
\hline & & & $\begin{array}{l}\text { Recruitment of circulating blood DCs and } \\
\text { monocytes to inflamed tissue }\end{array}$ & {$[43]$} \\
\hline CXCR3 & $\begin{array}{l}\text { CXCL9 } \\
\text { CXCL10/IP-10 } \\
\text { CXCL11 }\end{array}$ & $\begin{array}{l}\text { pDCs } \\
\text { immature } \mathrm{CD} \mathrm{a}^{+} \mathrm{DC}\end{array}$ & $\begin{array}{l}\text { Might be involved in the recruitment of } \mathrm{pDC} \text { and } \\
\text { immature } \mathrm{CDla}^{+} \mathrm{DCs} \text { to tissue lesions }\end{array}$ & {$[50,51]$} \\
\hline ChemR23 & Chemerin & Immature $\mathrm{pDCs}$ & $\begin{array}{l}\text { Migration plasmacytoid dendritic cells to } \\
\text { lymphoid organs and inflamed skin }\end{array}$ & {$[52,53]$} \\
\hline
\end{tabular}

indicated the possible role of CCR2 and CCR6 in control DCs migration by raising a novel model of how DCs in the blood migrate to inflamed epithelial surfaces: CCR2(+) circulating DC or DC precursors are mobilized into the tissue via the expression of MCP by cells lining blood vessels, and these cells traffic from the tissue to the site of pathogen invasion via the production of MIP-3alpha/CL20 by epithelial cells and the up-regulation of CCR6 in response to the tissue environment [43].

CCR3 is the chemokine receptor initially discovered on eosinophils. Study showed that it was also expressed by human DCs that differentiated from blood monocytes, DCs that emigrated from skin (epidermal and dermal DCs), and DCs derived from CD34 ${ }^{+}$hemopoietic precursors in bone marrow and umbilical cord blood. Unlike other chemokine receptors, such as CCR5 and CCR7, the expression of CCR3 is not dependent on the state of maturation. Indirect study by using CCR3 antibodies indicated the possible role of CCR3 in the DCs migration induced by its ligand eotaxin and eotaxin$2[42,44]$. Studies on the role of CCR3 in the DCs migration are few, and the specific role of CCR3 in control of subsets of DCs migration is still not clear.

In human, the role of CCR5 has also been indicated in DCs migration in some situations such as in HIV-1 infection and Acute Graft-Versus-Host Disease [45-47]. However, unlike mice $\mathrm{pDCs}$, the recruitment of $\mathrm{pDCs}$ appeared to be CCR5 independent. Pashenkov showed that expression of CCR5 was elevated on blood myeloid $\left(\mathrm{CD}_{11 c^{+}}\right) \mathrm{DC}$ in multiple sclerosis (MS) and optic neuritis patients compared to noninflammatory controls, its ligands RANTES and MIPlbeta were expressed in MS lesions, and the expression of CCR5 by myeloid DC in blood correlated with numbers of these cells in cerebrospinal fluid (CSF), which suggest that CCR5 may contribute to recruitment of myeloid DC $\left(\mathrm{CD} 11 \mathrm{c}^{+}\right)$to the CSF in these patients, but recruitment of plasmacytoid DC to CSF appeared to be CCR5-independent [46].

Studies also showed that CCR6 was expressed on leukemic pDCs and blood pDCs from melanoma patients and involved in the recruitment of $\mathrm{pDC}$ to lesions of skin $[48,49]$.

Most of the conclusions about the role of CCR7 on the human DCs migration came from the research on mouse DCs. The specific role of CCR7 in subsets of human DCs migration still needed to be confirmed as in mouse DCs.

It was found that in some inflamed situations such as in psoriatic lesions, pDCs found in the lesions were nearly all CXCR3(+), indirectly implicated the possible role for CXCR3 in mediating the recruitment of pDCs into the periphery tissue and developing lesions in human [50]. Besides its ligand CCL9-11, research about uveitis indicated that CXCR3 was involved in the immature DCs migration induced by retinal autoantigens $\mathrm{S}$-antigen $(\mathrm{S}-\mathrm{Ag}$ ) and interphotoreceptor retinoid binding protein (IRBP), suggesting its role in the autoimmune disease [51].

In human DCs, it was found that ChemR23 was expressed both on pDCs and myeloid DCs. Its ligand can induce the transmigration of plasmacytoid and myeloid 


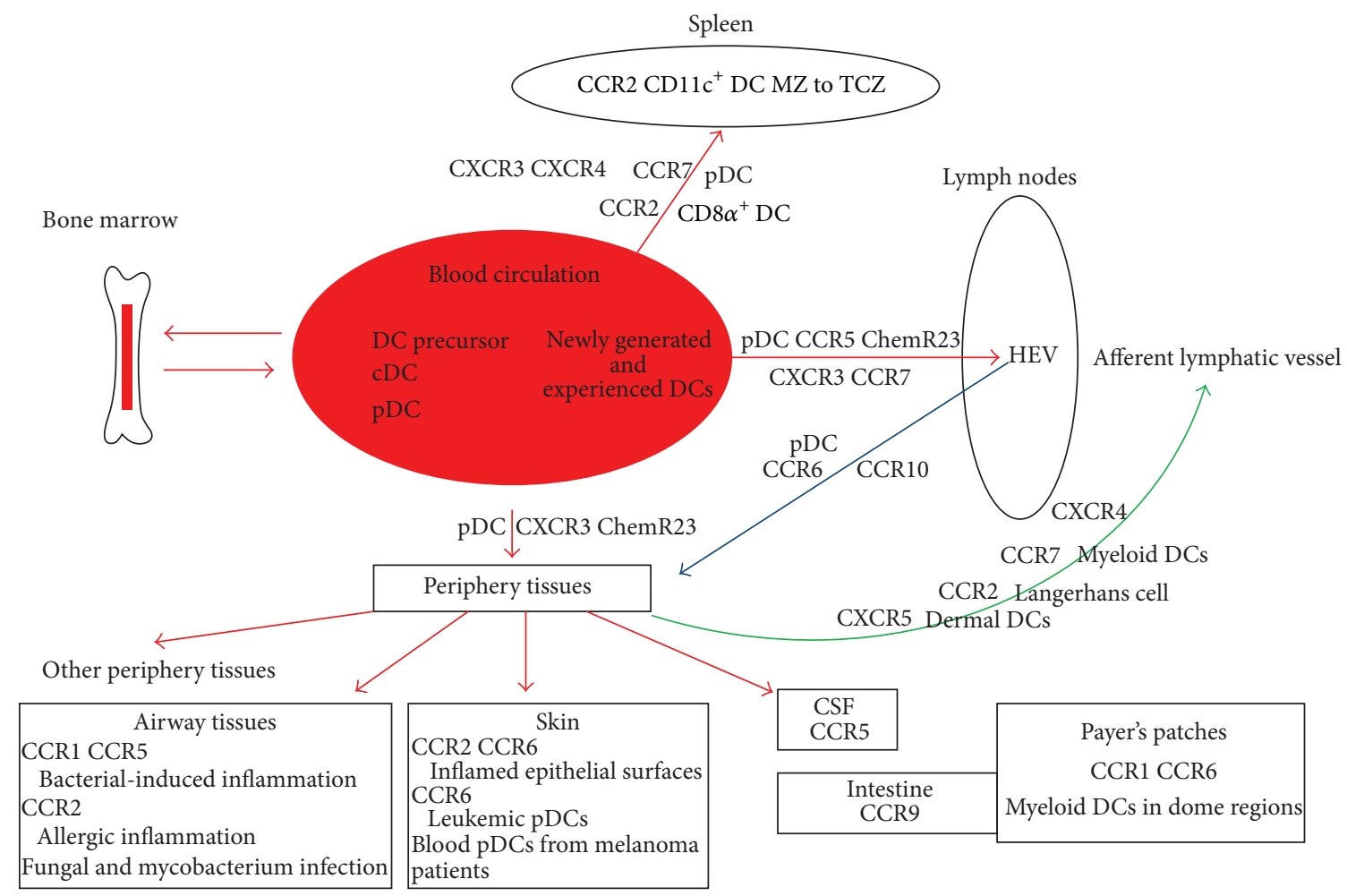

FIGURE 2: Chemokine receptors involved in migration of mouse and human DCs subsets. CCR7, CXCR4, CCR2, and CXCR5 are involved in subsets of cDCs migration from periphery tissues to draining LNs in both inflammation and steady-state. CCR5, ChemR23, CXCR3, and CCR7 are involved in migration of pDCs to LNs via hematogenous route. CCR2 is implicated in control of CD8 $\alpha^{+}$DC to the spleen and relocalization of $\mathrm{CD}_{11 \mathrm{c}^{+}} \mathrm{DC}$ from the marginal zone to the T cell areas in spleen. CCR7, CXCR3, and CXCR4 are shown to be involved in pDCs migration from blood to spleen. CCR1, CCR2, CCR5, and CCR6 are involved in the recruitment of cDCs to different tissues in specific situations. CCR9 is shown to have a role in controlling the migration of pDC to the small intestine under both steady-state and inflammatory conditions. In other situations of inflammation or tumor, CXCR3, ChemR23, and CCR6 are implicated to be involved in pDCs migration to periphery tissues.

DCs across an endothelial cell monolayer in vitro. The Chemerin $(+)$ endothelial cells were found to be surrounded by ChemR23(+) pDCs, which suggest a key role of the ChemR23/Chemerin axis in directing plasmacytoid DC trafficking [52]. Similarly, De Palma found that Chemerin was associated with tubular epithelial cells and renal lymphatic endothelial cells in patients with lupus nephritis but not in normal kidneys, and ChemR23-positive DCs had infiltrated the kidney tubulointerstitium in patients with severe lupus nephritis. The induced Chemerin can result in an efficient transendothelial migration of pDCs measured in transwell systems. These data suggest the role of ChemR23 in the recruitment of $\mathrm{pDCs}$ within the kidney in lupus nephritis patients [53].

The role of chemokines receptor in control of subsets of mouse and human DCs migration was summarized in Tables 1 and 2 and Figure 2.

\section{Signaling Pathways Involved in Chemokine Receptor Signaling}

All chemokine receptors are thought to couple to $G$ proteins. The heterotrimeric G-proteins consist of a $\alpha$-subunit that binds and hydrolyses GTP as well as a $\beta$ - and a $\gamma$-subunit that form an undissociable complex. Based on the types of their $\alpha$ subunits, $G$ proteins can be grouped into four subfamilies, they are $\mathrm{G} \alpha \mathrm{i}, \mathrm{G} \alpha \mathrm{s}, \mathrm{G} \alpha \mathrm{q} / 11$, and $\mathrm{G} 12 / 13$, each subfamily contains several members of G proteins [78].

The mechanism involved in the CCR7 signaling has been well studied; it is a multimodule model with the involvement of $\mathrm{G} \alpha \mathrm{i}, \mathrm{G} \alpha \mathrm{q}$, and $\mathrm{G} \alpha 12$ [79]. It was thought that chemotaxis induced by chemokine receptors was mainly through the $\mathrm{G} \alpha \mathrm{i}$ subfamily. The ligation of CCR7 and its ligands mediated the activation of $G$ proteins induced by the binding of GTP to $\mathrm{G} \alpha \mathrm{i}$ and the release of free $\beta \gamma$ subunits. The $\beta \gamma$ subunits subsequently activated downstream effectors such as PI3K which regulate the Akt pathway [80]. However, it seemed that these enzymes did not regulate either chemotaxis or the speed of DCs but regulated CCR7-dependent DC survival $[81,82]$. MAPK members ERK1/2, JNK, and p38 were also found to be activated and depended on $\mathrm{G} \alpha \mathrm{i}$ in the CCR7 signaling cascades and played an important role in regulating DCs chemotaxis. Besides the role of $\mathrm{G} \alpha \mathrm{i}$ in the chemokine receptors signaling pathway, in recent years, chemokine receptors coupled to other $\mathrm{G}$ protein subfamilies has also been demonstrated. Study found that Gnaq-/- DCs 
were unable to migrate to inflammatory sites and LNs in vivo, which indicated the role of $\mathrm{G} \alpha \mathrm{q}$ in the chemokine receptor signaling. $\mathrm{G} \alpha \mathrm{q}$, like CD38, regulated the extracellular calcium entry in chemokine-stimulated cells [83]. In addition to $\mathrm{G} \alpha \mathrm{q}$, CCR7 also used another pathway involving Rho/Pyk2/cofilin and presumably depended on G12/G13 to control the migratory speed of DCs [81].

\section{Perspectives}

Several families of chemokines receptors and their chemokine ligands orchestrate subsets of DCs trafficking. For cDCs, CCR7 plays a central role in the migration of mature DCs to the draining LNs via lymphatic vessels during both inflammation and steady-state conditions, with a multimodule signaling model that involved $\mathrm{G} \alpha \mathrm{i}, \mathrm{G} \alpha \mathrm{q}$, and G $\alpha 12$. CXCR4, CCR2, and CXCR5 have also been implicated to be involved in some subsets of $\mathrm{CDCs}$ migration from periphery tissues to draining LNs. CCR2 is also implicated in control of $\mathrm{CD} 8 \alpha^{+}$DC to the spleen and relocalization

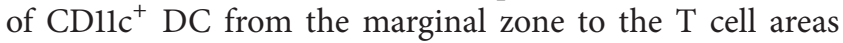
in spleen. CCR1, CCR2, CCR5, and CCR6 are involved in the recruitment of $\mathrm{CDCs}$ to different tissues in specific situations. pDCs use a very different migratory patterns compared with cDCs. For pDCs, CCR5, ChemR23, CXCR3, and CCR7 are involved in migration of pDCs to LNs via hematogenous route, though the role of CCR5 versus CXCR3 and role of CCR7 in pDCs migration remains controversial. CCR7, CXCR3, and CXCR4 are shown to be involved in pDCs migration from blood to spleen. CCR9 is shown to have a role in controlling the migration of $\mathrm{pDC}$ to the small intestine under both steady-state and inflammatory conditions. In other situations of inflammation or tumor, CXCR3, ChemR23, and CCR6 are implicated to be involved in $\mathrm{pDCs}$ migration to periphery tissues.

However, there are still some limitations in the present studies on the role of chemokines receptors in the control of DCs migration. Some conclusions on the role of chemokines receptors in subsets of DCs migration came from indirect evidence by studying the expression change of chemokine receptors on DCs or by using an antagonist of a chemokine receptor to draw a possible conclusion. Experiments using chemokines receptors knockout mice also have their limitations, because it can affects a wide variety of cells potentially implicated in the inflammation. Studies using in vitro derived DCs may not accurately mirror the situations occurring in vivo. The role of chemokines receptors in the control of migration of a specific subset of DCs remains to be defined which causes the different roles of subsets of DCs in immune regulation. Understanding this complex orchestration of chemokines receptors in the subsets of DCs migration will be essential to manipulate efficiently the function of a specific subset of DCs and facilitate our clinical treatment in multiple diseases in which DCs are involved.

\section{Conflict of Interests}

The authors declare that there is no conflict of interests.

\section{Acknowledgments}

This work was partially supported by the Natural Science Foundation of China (NSFC) Grant 30830094, 30972678 to Dr. Guixiu Shi.

\section{References}

[1] R. M. Thurlings, C. A. Wijbrandts, R. J. Bennink et al., "Monocyte scintigraphy in rheumatoid arthritis: the dynamics of monocyte migration in immune-mediated inflammatory disease," PLoS ONE, vol. 4, no. 11, Article ID e7865, 2009.

[2] M. U. Norman and M. J. Hickey, "Mechanisms of lymphocyte migration in autoimmune disease," Tissue Antigens, vol. 66, no. 3, pp. 163-172, 2005.

[3] J. Marsal and W. W. Agace, "Targeting T-cell migration in inflammatory bowel disease," Journal of Internal Medicine, vol. 272, no. 5, pp. 411-429, 2012.

[4] C. R. Mackay, "Moving targets: cell migration inhibitors as new anti-inflammatory therapies," Nature Immunology, vol. 9, no. 9, pp. 988-998, 2008.

[5] A. D. Luster, R. Alon, and U. H. von Andrian, "Immune cell migration in inflammation: present and future therapeutic targets," Nature Immunology, vol. 6, no. 12, pp. 1182-1190, 2005.

[6] J. Banchereau and R. M. Steinman, "Dendritic cells and the control of immunity," Nature, vol. 392, no. 6673, pp. 245-252, 1998.

[7] R. M. Steinman, "Some interfaces of dendritic cell biology," APMIS, vol. 111, no. 7-8, pp. 675-697, 2003.

[8] V. Katritch, V. Cherezov, and R. C. Stevens, "Structure-function of the G protein-coupled receptor superfamily," Annual Review of Pharmacology and Toxicology, vol. 53, pp. 531-556, 2013.

[9] Y. Maeda, H. Matsuyuki, K. Shimano, H. Kataoka, K. Sugahara, and K. Chiba, "Migration of CD4 T cells and dendritic cells toward sphingosine 1-phosphate (S1P) is mediated by different receptor subtypes: S1P regulates the functions of murine mature dendritic cells via S1P receptor type 3," Journal of Immunology, vol. 178, no. 6, pp. 3437-3446, 2007.

[10] L. C. Chan, W. Peters, Y. Xu, J. Chun, R. V. Farese Jr., and S. Cases, "LPA3 receptor mediates chemotaxis of immature murine dendritic cells to unsaturated lysophosphatidic acid (LPA)," Journal of Leukocyte Biology, vol. 82, no. 5, pp. 11931200, 2007.

[11] M. Jurewicz, D. H. McDermott, J. M. Sechler et al., "Human T and natural killer cells possess a functional renin-angiotensin system: further mechanisms of angiotensin II-induced inflammation," Journal of the American Society of Nephrology, vol. 18, no. 4, pp. 1093-1102, 2007.

[12] R. M. Steinman and Z. A. Cohn, "Identification of a novel cell type in peripheral lymphoid organs of mice. I. Morphology, quantitation, tissue distribution," Journal of Experimental Medicine, vol. 137, no. 5, pp. 1142-1162, 1973.

[13] K. Shortman and W. R. Heath, "The CD8+ dendritic cell subset," Immunological Reviews, vol. 234, no. 1, pp. 18-31, 2010.

[14] J. Helft, F. Ginhoux, M. Bogunovic, and M. Merad, "Origin and functional heterogeneity of non-lymphoid tissue dendritic cells in mice," Immunological Reviews, vol. 234, no. 1, pp. 55-75, 2010.

[15] M. Collin, N. McGovern, and M. Haniffa, "Human dendritic cell subsets," Immunology, vol. 140, no. 1, pp. 22-30, 2013.

[16] M. Merad, P. Sathe, J. Helft, J. Miller, and A. Mortha, "The dendritic cell lineage: ontogeny and function of dendritic cells 
and their subsets in the steady state and the inflamed setting," Annual Review of Immunology, vol. 31, pp. 563-604, 2013.

[17] S. H. Naik, P. Sathe, H.-Y. Park et al., "Development of plasmacytoid and conventional dendritic cell subtypes from single precursor cells derived in vitro and in vivo," Nature Immunology, vol. 8, no. 11, pp. 1217-1226, 2007.

[18] K. McKenna, A.-S. Beignon, and N. Bhardwaj, "Plasmacytoid dendritic cells: linking innate and adaptive immunity," Journal of Virology, vol. 79, no. 1, pp. 17-27, 2005.

[19] D. Rossi and A. Zlotnik, "The biology of chemokines and their receptors," Annual Review of Immunology, vol. 18, pp. 217-243, 2000.

[20] M.-C. Dieu, B. Vanbervliet, A. Vicari et al., "Selective recruitment of immature and mature dendritic cells by distinct chemokines expressed in different anatomic sites," Journal of Experimental Medicine, vol. 188, no. 2, pp. 373-386, 1998.

[21] C. Murdoch and A. Finn, "Chemokine receptors and their role in inflammation and infectious diseases," Blood, vol. 95, no. 10, pp. 3032-3043, 2000.

[22] X. Zhao, A. Sato, C. S. Dela Cruz et al., "CCL9 is secreted by the follicle-associated epithelium and recruits dome region Peyer's patch CD11b+ dendritic cells," Journal of Immunology, vol. 171, no. 6, pp. 2797-2803, 2003.

[23] P. A. Stumbles, D. H. Strickland, C. L. Pimm et al., "Regulation of dendritic cell recruitment into resting and inflamed airway epithelium: use of alternative chemokine receptors as a function of inducing stimulus," Journal of Immunology, vol. 167, no. 1, pp. 228-234, 2001.

[24] L. J. Robays, T. Maes, S. Lebecque et al., "Chemokine receptor CCR2 but not CCR5 or CCR6 mediates the increase in pulmonary dendritic cells during allergic airway inflammation," Journal of Immunology, vol. 178, no. 8, pp. 5305-5311, 2007.

[25] S. Provoost, T. Maes, G. F. Joos, and K. G. Tournoy, "Monocytederived dendritic cell recruitment and allergic $\mathrm{TH} 2$ responses after exposure to diesel particles are CCR2 dependent," Journal of Allergy and Clinical Immunology, vol. 129, no. 2, pp. 483-491, 2012.

[26] J. J. Osterholzer, J. L. Curtis, T. Polak et al., "CCR2 mediates conventional dendritic cell recruitment and the formation of bronchovascular mononuclear cell infiltrates in the lungs of mice infected with cryptococcus neoformans," Journal of Immunology, vol. 181, no. 1, pp. 610-620, 2008.

[27] W. Peters, J. G. Cyster, M. Mack et al., "CCR2-dependent trafficking of F4/80dim macrophages and CD1lcdim/intermediate dendritic cells is crucial for T cell recruitment to lungs infected with Mycobacterium tuberculosis," Journal of Immunology, vol. 172, no. 12, pp. 7647-7653, 2004.

[28] N. Sato, S. K. Ahuja, M. Quinones et al., "CC chemokine receptor (CCR)2 is required for langerhans cell migration and localization of $\mathrm{T}$ helper cell type 1 (Thl)-inducing dendritic cells: absence of CCR2 shifts the Leishmania major-resistant phenotype to a susceptible state dominated by Th2 cytokines, B cell outgrowth, and sustained neutrophilic inflammation," Journal of Experimental Medicine, vol. 192, no. 2, pp. 205-218, 2000.

[29] T. G. Diacovo, A. L. Blasius, T. W. Mak, M. Cella, and M. Colonna, "Adhesive mechanisms governing interferonproducing cell recruitment into lymph nodes," Journal of Experimental Medicine, vol. 202, no. 5, pp. 687-696, 2005.

[30] D. N. Cook, D. M. Prosser, R. Forster et al., "CCR6 mediates dendritic cell localization, lymphocyte homeostasis, and immune responses in mucosal tissue," Immunity, vol. 12, no. 5, pp. 495-503, 2000.

[31] R. Varona, R. Villares, L. Carramolino et al., "CCR6-deficient mice have impaired leukocyte homeostasis and altered contact hypersensitivity and delayed-type hypersensitivity responses," Journal of Clinical Investigation, vol. 107, no. 6, pp. R37-R45, 2001.

[32] M. Le Borgne, N. Etchart, A. Goubier et al., "Dendritic cells rapidly recruited into epithelial tissues via CCR6/CCL20 are responsible for CD8+ T cell crosspriming in vivo," Immunity, vol. 24, no. 2, pp. 191-201, 2006.

[33] V. Sisirak, N. Vey, B. Vanbervliet et al., "CCR6/CCR10-mediated plasmacytoid dendritic cell recruitment to inflamed epithelia after instruction in lymphoid tissues," Blood, vol. 118, no. 19, pp. 5130-5140, 2011.

[34] L. Ohl, M. Mohaupt, N. Czeloth et al., "CCR7 governs skin dendritic cell migration under inflammatory and steady-state conditions," Immunity, vol. 21, no. 2, pp. 279-288, 2004.

[35] S. Seth, L. Oberdörfer, R. Hyde et al., "CCR7 essentially contributes to the homing of plasmacytoid dendritic cells to lymph nodes under steady-state as well as inflammatory conditions," Journal of Immunology, vol. 186, no. 6, pp. 3364-3372, 2011.

[36] E. Umemoto, K. Otani, T. Ikeno et al., "Constitutive plasmacytoid dendritic cell migration to the splenic white pulp is cooperatively regulated by CCR7- and CXCR4-mediated signaling," Journal of Immunology, vol. 189, no. 1, pp. 191-199, 2012.

[37] M. Wendland, N. Czeloth, N. Mach et al., "CCR9 is a homing receptor for plasmacytoid dendritic cells to the small intestine," Proceedings of the National Academy of Sciences of the United States of America, vol. 104, no. 15, pp. 6347-6352, 2007.

[38] H. Yoneyama, K. Matsuno, Y. Zhang et al., "Evidence for recruitment of plasmacytoid dendritic cell precursors to inflamed lymph nodes through high endothelial venules," International Immunology, vol. 16, no. 7, pp. 915-928, 2004.

[39] C. Asselin-Paturel, G. Brizard, K. Chemin et al., "Type I interferon dependence of plasmacytoid dendritic cell activation and migration," Journal of Experimental Medicine, vol. 201, no. 7, pp. 1157-1167, 2005.

[40] K. Kabashima, N. Shiraishi, K. Sugita et al., "CXCL12-CXCR4 engagement is required for migration of cutaneous dendritic cells," American Journal of Pathology, vol. 171, no. 4, pp. 12491257, 2007.

[41] M.-T. Wu and S. T. Hwang, "CXCR5-transduced bone marrowderived dendritic cells traffic to B cell zones of lymph nodes and modify antigen-specific immune responses," Journal of Immunology, vol. 168, no. 10, pp. 5096-5102, 2002.

[42] K. Sato, H. Kawasaki, H. Nagayama et al., "CC chemokine receptors, CCR-1 and CCR-3, are potentially involved in antigen-presenting cell function of human peripheral blood monocyte-derived dendritic cells," Blood, vol. 93, no. 1, pp. 3442, 1999.

[43] B. Vanbervliet, B. Homey, I. Durand et al., "Sequential involvement of CCR2 and CCR6 ligands for immature dendritic cell recruitment: possible role at inflamed epithelial surfaces," European Journal of Immunology, vol. 32, no. 1, pp. 231-242, 2002.

[44] S. Beaulieu, D. F. Robbiani, X. Du et al., "Expression of a functional eotaxin (CC chemokine ligand 11) receptor CCR3 by human dendritic cells," Journal of Immunology, vol. 169, no. 6, pp. 2925-2936, 2002. 
[45] M. Cavarelli, C. Foglieni, M. Rescigno, and G. Scarlatti, "R5 HIV-1 envelope attracts dendritic cells to cross the human intestinal epithelium and sample luminal virions via engagement of the CCR5," EMBO Molecular Medicine, vol. 5, no. 5, pp. 776-794, 2013.

[46] M. Pashenkov, N. Teleshova, M. Kouwenhoven et al., "Elevated expression of CCR5 by myeloid (CD11c+) blood dendritic cells in multiple sclerosis and acute optic neuritis," Clinical and Experimental Immunology, vol. 127, no. 3, pp. 519-526, 2002.

[47] K. Shahin, M. Sartor, D. N. Hart, and K. F. Bradstock, "Alterations in chemokine receptor CCR5 expression on blood dendritic cells correlate with acute graft-versus-host disease," Transplantation, vol. 96, no. 8, pp. 753-762, 2013.

[48] J. Charles, J. Di Domizio, D. Salameire et al., "Characterization of circulating dendritic cells in melanoma: role of CCR6 in plasmacytoid dendritic cell recruitment to the tumor," Journal of Investigative Dermatology, vol. 130, no. 6, pp. 1646-1656, 2010.

[49] N. B. Vermare, L. Chaperot, M. Peoc'h et al., "In situ leukemic plasmacytoid dendritic cells pattern of chemokine receptors expression and in vitro migratory response," Leukemia, vol. 18, no. 9, pp. 1491-1498, 2004.

[50] S.-C. Chen, M. De Groot, D. Kinsley et al., "Expression of chemokine receptor CXCR3 by lymphocytes and plasmacytoid dendritic cells in human psoriatic lesions," Archives of Dermatological Research, vol. 302, no. 2, pp. 113-123, 2010.

[51] O. M. Z. Howard, F. D. Hui, B. S. Shao et al., "Autoantigens signal through chemokine receptors: uveitis antigens induce CXCR3and CXCR5-expressing lymphocytes and immature dendritic cells to migrate," Blood, vol. 105, no. 11, pp. 4207-4214, 2005.

[52] W. Vermi, E. Riboldi, V. Wittamer et al., "Role of ChemR23 in directing the migration of myeloid and plasmacytoid dendritic cells to lymphoid organs and inflamed skin," Journal of Experimental Medicine, vol. 201, no. 4, pp. 509-515, 2005.

[53] G. De Palma, G. Castellano, A. Del Prete et al., "The possible role of ChemR23/Chemerin axis in the recruitment of dendritic cells in lupus nephritis," Kidney International, vol. 79, no. 11, pp. 1228-1235, 2011.

[54] A. Vecchi, L. Massimiliano, S. Ramponi et al., "Differential responsiveness to constitutive vs. inducible chemokines of immature and mature mouse dendritic cells," Journal of Leukocyte Biology, vol. 66, no. 3, pp. 489-494, 1999.

[55] F. Jimenez, M. P. Quinones, H. G. Martinez et al., “CCR2 plays a critical role in dendritic cell maturation: possible role of CCL2 and NF- $\kappa$ B," Journal of Immunology, vol. 184, no. 10, pp. 55715581, 2010.

[56] B. Lee, M. Sharron, L. J. Montaner, D. Weissman, and R. W. Doms, "Quantification of CD4, CCR5, and CXCR4 levels on lymphocyte subsets, dendritic cells, and differentially conditioned monocyte-derived macrophages," Proceedings of the National Academy of Sciences of the United States of America, vol. 96, no. 9, pp. 5215-5220, 1999.

[57] N. Tedla, H.-W. Wang, H. P. McNeil et al., "Regulation of T lymphocyte trafficking into lymph nodes during an immune response by the chemokines macrophage inflammatory protein (MIP)- $1 \alpha$ and MIP-1 $\beta$," Journal of Immunology, vol. 161, no. 10, pp. 5663-5672, 1998.

[58] N. Tedla, P. Palladinetti, D. Wakefield, and A. Lloyd, "Abundant expression of chemokines in malignant and infective human lymphadenopathies," Cytokine, vol. 11, no. 7, pp. 531-540, 1999.

[59] T. Kucharzik, J. T. Hudson, R. L. Waikel, W. D. Martin, and I. R. Williams, "CCR6 expression distinguishes mouse myeloid and lymphoid dendritic cell subsets: demonstration using a CCR6 EGFP knock-in mouse," European Journal of Immunology, vol. 32, no. 1, pp. 104-112, 2002.

[60] R. Förster, A. Schubel, D. Breitfeld et al., "CCR7 coordinates the primary immune response by establishing functional microenvironments in secondary lymphoid organs," Cell, vol. 99, no. 1, pp. 23-33, 1999.

[61] G. J. Randolph, J. Ochando, and S. Partida-Sánchez, "Migration of dendritic cell subsets and their precursors," Annual Review of Immunology, vol. 26, pp. 293-316, 2008.

[62] G. Vassileva, H. Soto, A. Zlotnik et al., "The reduced expression of 6Ckine in the plt mouse results from the deletion of one of two 6Ckine genes," Journal of Experimental Medicine, vol. 190, no. 8, pp. 1183-1188, 1999.

[63] M. H. Jang and M. Miyasaka, "CCR7 is critically important for migration of dendritic cells in intestinal lamina propria to mesenteric lymph nodes," Journal of Immunology, vol. 176, no. 2, pp. 803-810, 2006.

[64] P. Brawand, D. R. Fitzpatrick, B. W. Greenfield, K. Brasel, C. R. Maliszewski, and T. De Smedt, "Murine plasmacytoid predendritic cells generated from Flt3 ligand-supplemented bone marrow cultures are immature APCs," Journal of Immunology, vol. 169, no. 12, pp. 6711-6719, 2002.

[65] M. D. Gunn, "Chemokine mediated control of dendritic cell migration and function," Seminars in Immunology, vol. 15, no. 5, pp. 271-276, 2003.

[66] M. L. Drakes, P. J. Stiff, and T. G. Blanchard, "Inverse relationship between dendritic cell CCR9 expression and maturation state," Immunology, vol. 127, no. 4, pp. 466-476, 2009.

[67] A. M. Norment, L. Y. Bogatzki, B. N. Gantner, and M. J. Bevan, "Murine CCR9, a chemokine receptor for thymus-expressed chemokine that is up-regulated following pre-TCR signaling," Journal of Immunology, vol. 164, no. 2, pp. 639-648, 2000.

[68] K. A. Papadakis, C. Landers, J. Prehn et al., "CC chemokine receptor 9 expression defines a subset of peripheral blood lymphocytes with mucosal $\mathrm{T}$ cell phenotype and Thl or Tregulatory 1 cytokine profile," Journal of Immunology, vol. 171, no. 1, pp. 159-165, 2003.

[69] H. Hadeiba, T. Sato, A. Habtezion, C. Oderup, J. Pan, and E. C. Butcher, "CCR9 expression defines tolerogenic plasmacytoid dendritic cells able to suppress acute graft-versus-host disease," Nature Immunology, vol. 9, no. 11, pp. 1253-1260, 2008.

[70] S. Mizuno, T. Kanai, Y. Mikami et al., "CCR9+ plasmacytoid dendritic cells in the small intestine suppress development of intestinal inflammation in mice," Immunology Letters, vol. 146, no. 1-2, pp. 64-69, 2012.

[71] M. Á. García-López, F. Sánchez-Madrid, J. M. Rodríguez-Frade et al., "CXCR3 chemokine receptor distribution in normal and inflamed tissues: expression on activated lymphocytes, endothelial cells, and dendritic cells," Laboratory Investigation, vol. 81, no. 3, pp. 409-418, 2001.

[72] R. Förster, T. Emrich, E. Kremmer, and M. Lipp, "Expression of the G-protein-coupled receptor BLR1 defines mature, recirculating B cells and a subset of T-helper memory cells," Blood, vol. 84, no. 3, pp. 830-840, 1994.

[73] H. Saeki, M. T. Wu, E. Olasz, and S. T. Hwang, "A migratory population of skin-derived dendritic cells expresses CXCR5, responds to $\mathrm{B}$ lymphocyte chemoattractant in vitro, and colocalizes to B cell zones in lymph nodes in vivo," European Journal of Immunology, vol. 30, no. 10, pp. 2808-2814, 2000.

[74] S. Luangsay, V. Wittamer, B. Bondue et al., "Mouse ChemR23 is expressed in dendritic cell subsets and macrophages, and 
mediates an anti-inflammatory activity of chemerin in a lung disease model," Journal of Immunology, vol. 183, no. 10, pp. 6489-6499, 2009.

[75] B. A. Zabel, A. M. Silverio, and E. C. Butcher, "Chemokine-like receptor 1 expression and chemerin-directed chemotaxis distinguish plasmacytoid from myeloid dendritic cells in human blood," Journal of Immunology, vol. 174, no. 1, pp. 244-251, 2005.

[76] S. Varani, G. Frascaroli, M. Homman-Loudiyi, S. Feld, M. P. Landini, and C. Söderberg-Nauclér, "Human cytomegalovirus inhibits the migration of immature dendritic cells by downregulating cell-surface CCR1 and CCR5," Journal of Leukocyte Biology, vol. 77, no. 2, pp. 219-228, 2005.

[77] R. T. Semnani, L. Mahapatra, B. Dembele et al., "Expanded numbers of circulating myeloid dendritic cells in patent human filarial infection reflect lower CCR1 expression," Journal of Immunology, vol. 185, no. 10, pp. 6364-6372, 2010.

[78] Y. Wang, Y. Li, and G. Shi, "The regulating function of heterotrimeric G proteins in the immune system," Archivum Immunologiae et Therapiae Experimentalis, vol. 61, no. 4, pp. 309-319, 2013.

[79] N. Sánchez-Sánchez, L. Riol-Blanco, and J. L. RodríguezFernández, "The multiple personalities of the chemokine receptor CCR7 in dendritic cells," Journal of Immunology, vol. 176, no. 9, pp. 5153-5159, 2006.

[80] A. Del Prete, W. Vermi, E. Dander et al., "Defective dendritic cell migration and activation of adaptive immunity in PI3K $\gamma$ deficient mice," EMBO Journal, vol. 23, no. 17, pp. 3505-3515, 2004.

[81] L. Riol-Blanco, N. Sánchez-Sánchez, A. Torres et al., “The chemokine receptor CCR7 activates in dendritic cells two signaling modules that independently regulate chemotaxis and migratory speed," Journal of Immunology, vol. 174, no. 7, pp. 4070-4080, 2005.

[82] N. Sánchez-Sánchez, L. Riol-Blanco, G. De La Rosa et al., "Chemokine receptor CCR7 induces intracellular signaling that inhibits apoptosis of mature dendritic cells," Blood, vol. 104, no. 3, pp. 619-625, 2004.

[83] G. Shi, S. Partida-Sánchez, R. S. Misra et al., "Identification of an alternative $\mathrm{G} \alpha \mathrm{q}$-dependent chemokine receptor signal transduction pathway in dendritic cells and granulocytes," Journal of Experimental Medicine, vol. 204, no. 11, pp. 2705-2718, 2007. 

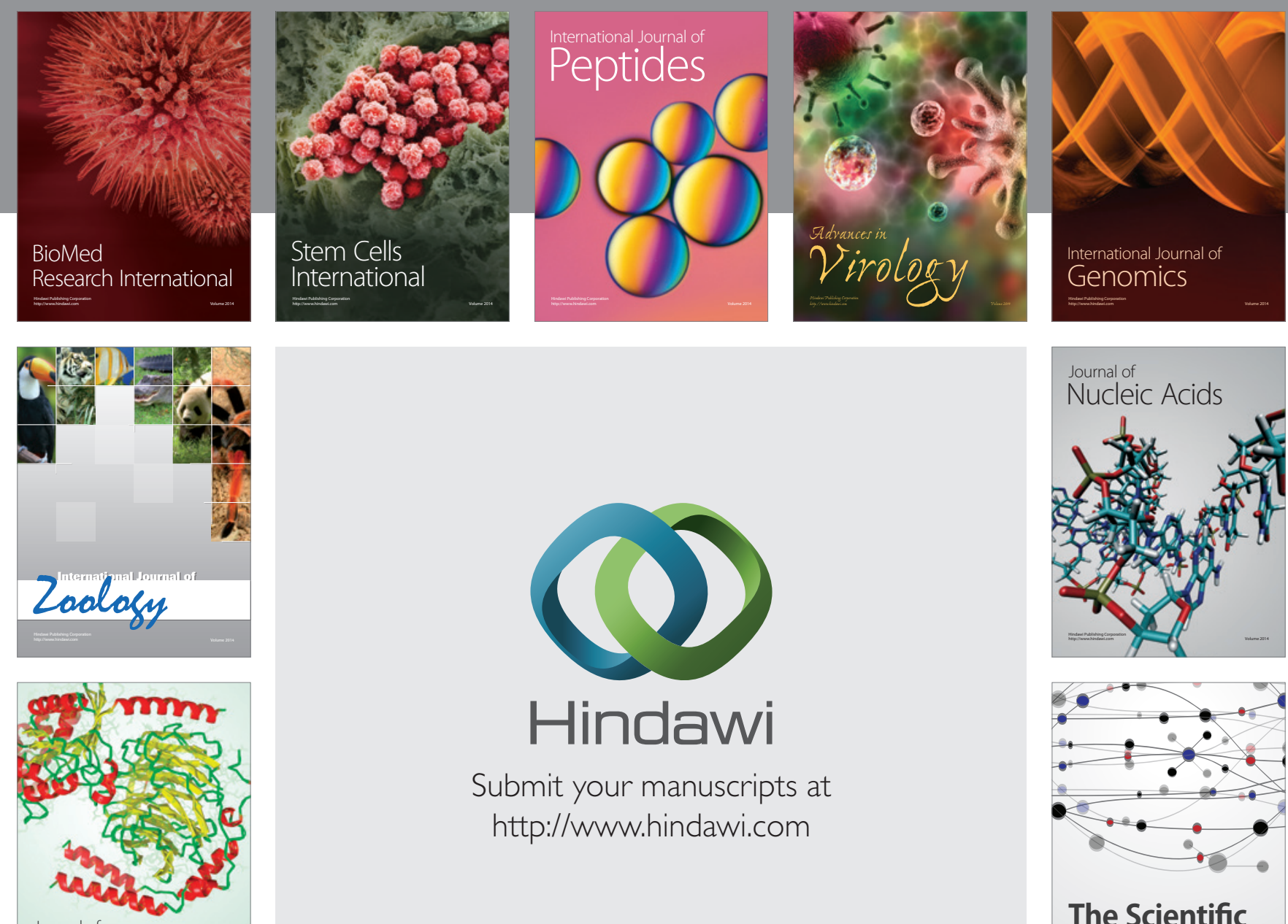

Submit your manuscripts at

http://www.hindawi.com

Journal of
Signal Transduction
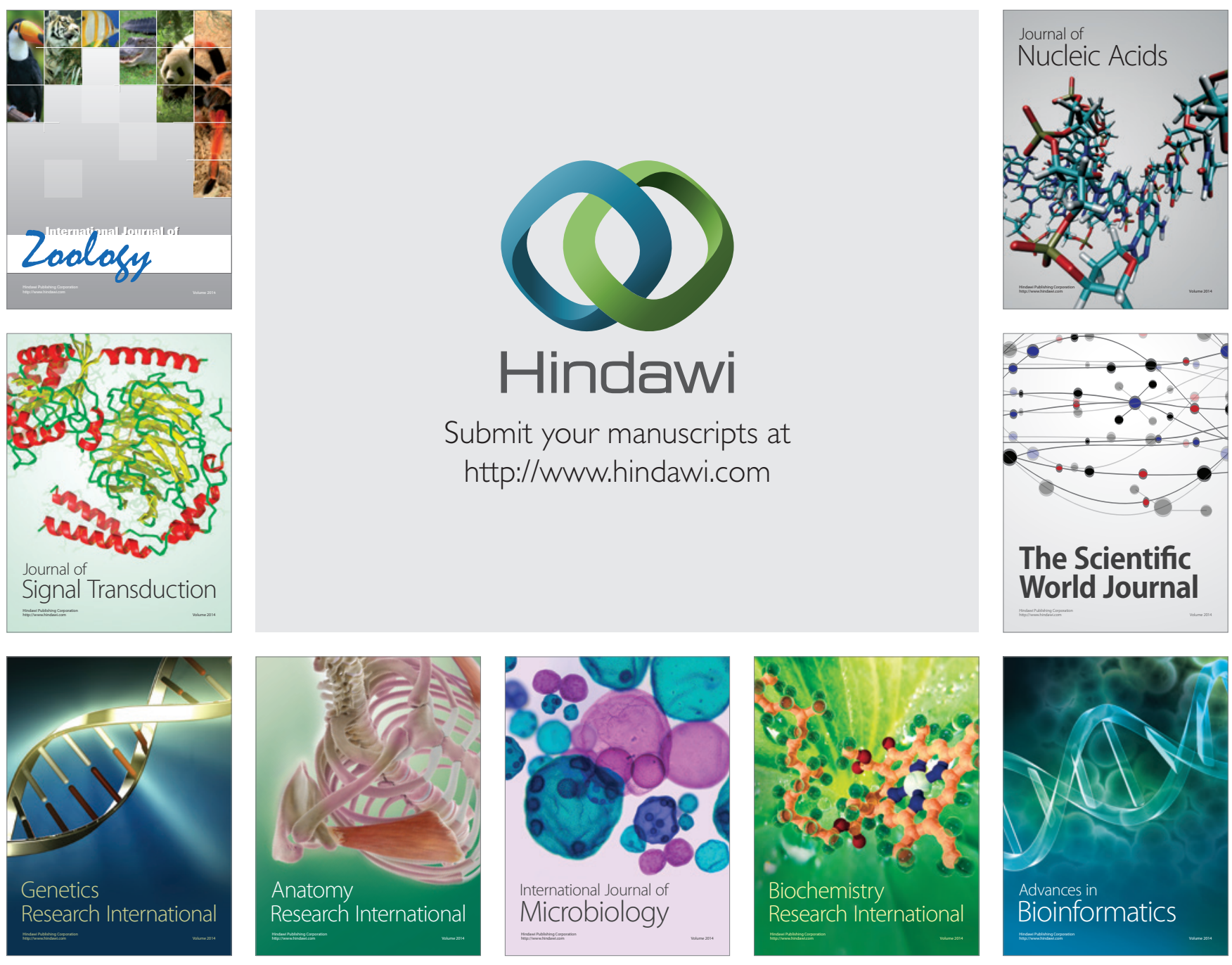

The Scientific World Journal
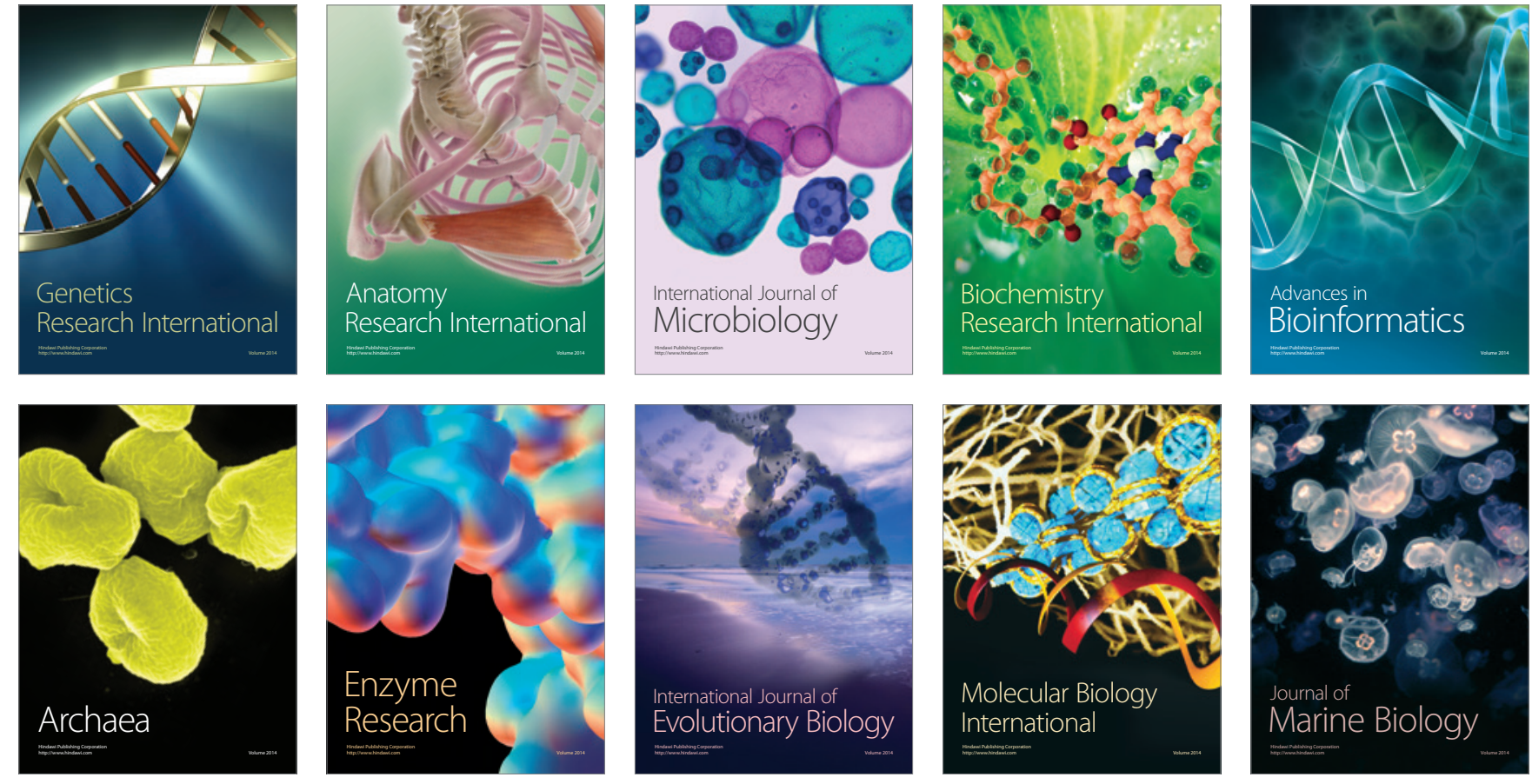